\title{
What's Wrong with Learning for the Exam? An Assessment-Based Approach for Student Engagement
}

\author{
Hiroshi Ito ${ }^{1}$ \\ ${ }^{1}$ School of Management, Nagoya University of Commerce and Business, Aichi, Japan \\ Correspondence: Hiroshi Ito, School of Management, Nagoya University of Commerce and Business, 4-4 \\ Sagamine, Komenoki-cho, Nisshin-shi, Aichi-ken, 470-0193, Japan. Tel: 81-561-73-2111. E-mail: \\ hito@nucba.ac.jp
}

Received: January 12, 2014

Accepted: April 24, $2014 \quad$ Online Publishe: May 14, 2014

doi:10.5539/jel.v3n2p145

URL: http://dx.doi.org/10.5539/jel.v3n2p145

\begin{abstract}
It is now widely recognized that assessment and the feedback play key roles in the learning process. However, assessment-based learning approaches are not yet commonly practiced in Japan. This paper provides an example of an assessment-based approach to teaching and learning employed for a course entitled "English as an International Language" offered at the Nagoya University of Commerce and Business in Japan. The course objective was to help develop critical thinking, analytical reasoning, creative thinking, writing, and communication skills through examining the sociolinguistic landscape surrounding the English language in Japan. ICE (Idea-Connection-Extension) methodology was used to assess the course. Students actively engaged in the coursework and their feedback to the course was positive.
\end{abstract}

Keywords: assessment-based approach, active learning, student engagement

\section{Introduction}

\subsection{Assessment-Based Approach}

It is now widely recognized that assessment and feedback play key roles in the learning process (Boud and Falchikov, 2006; Crisp, 2012; Foster et al., 2012; Hernandez, 2012; Keating et al., 2012; William et al., 2004). As Foster et al. (2012) argue, while many students may not engage with their courses, they do engage with assessment. This student engagement derives from extrinsic motivation (e.g., a desire to obtain good grades) as opposed to intrinsic motivation (e.g., curiosity or interest) (Lepper et al., 2005). In higher education, intrinsically motivated learning, linked to a deep approach to learning, is generally preferred (Peters, 2011; Tippin et al., 2002; Torrance, 2012). On the other hand, "[e]xtrinsic motivation, such as assessment-driven [approaches], is less desired academically as it is associated with a surface approach to learning" (Donnison and Penn-Edwards, 2012, p. 16). However, studies have shown that assessment enhances student learning (Bols, 2012; Dyer, 2013; Fink, 2003; McDonell, 2012; Sambell et al., 2012). Sambell et al. (2012), for example, explain that assessment has a so-called "backwash effect" on students' learning because "students often use the assessment system as a key indicator of what it is they are supposed to learn and how they are required to demonstrate their learning" (p. 4). Nonetheless, how to provide formative tasks and feedback effectively is another issue. Hernandez (2012) argues that many university instructors or students consider feedback "a grade," "a few comments," or "only a sentence at the end, not very helpful" (p. 497).

With this in mind, this paper provides an example of an assessment-based approach to teaching and learning employed for an elective course entitled "English as an International Language" offered at the Nagoya University of Commerce and Business in Japan. The course objective was to help develop critical thinking, analytical reasoning, creative thinking, writing, and communication skills through examining the sociolinguistic landscape surrounding the English language in Japan. The course consisted of seven 100-minute sessions and a final exam. This course mainly targeted second and third year students whose averaged ages are 20 and majors are Commerce, Business, or Economics. The class size was 17, one of whom was female. This course took place for the first time in 2013. 


\subsection{Active Learning}

The assessment-based approach entails active learning components to engage "somewhat lifeless students sitting passively in classrooms" (Smart et al., 2012, p. 392) as it places students at the center of the assessment process and involves them as co-producers of learning (Bols, 2012). Active learning can be defined as learning by doing based on hands-on experience (Greene, 2011). Prince (2004) cites collaborative learning and problem-based learning (PBL) as main instructional methods of active learning. Collaborative learning occurs when students work together in a group for learning activities. PBL is learning through the process of solving "real-world" problems. In my course, as explained later, students mostly worked in teams and also actively learn through "creating problems" relevant to real-world issues such as learning English for the 2020 Tokyo Olympic Games or teaching English education at elementary school. Throughout the course, students were actively doing the research, reading articles, and writing responses rather than having information relayed to them in a lecture or a PowerPoint.

\subsection{Criticism}

Some may raise the critique that an assessment-based approach could cause students to only study topics related to the final exam and thus the information that they acquire may be limited. Indeed, as Peters (2011) explains, courses with active learning elements are more time consuming than lecture-based courses and "the integration of active learning necessitates a reduction in the volume of knowledge and skills" (p. 468).

However, students learn more deeply through assessment-based approaches as they engage more in assessment (Peters, 2011). Also, even if students are given a lecture that covers a great deal of information, they may not retain it due to mental lapse (Rowe, 1983). "Without the retention of knowledge, ideas or information, students are unable to connect and apply it in real life (Young, 2005). Active learning helps both retain and apply knowledge (Rutherford, 2012).

\subsection{ICE Assessment Model}

ICE, a qualitative learning assessment model, was employed to formatively assess and to help students learn (Young \& Wilson, 1995). "I" refers to Idea, "C" refers to Connection, and "E" refers to Extension. Ideas refer to basic knowledge and information developed toward new learning. Connections comprise of two levels: the content level and the personal meaning-making level. Students at the content level are able to identify relationships among different ideas. Students at the personal meaning-making level are able to relate their knowledge to new learning including innovation and problem solving. Extension is the application of knowledge in different contexts. Young and Wilson (1995) provide an example of a broken toaster to explain this process. When a teacher asks students what is wrong with the toaster, just describing the fact that the toaster is broken is at the stage of "I." If students explain why the toaster is broken, then they are at the state of "C" because they identify the relationships between the cause and result. If students can suggest how to repair the toaster, then they are at the stage of "E" as they apply their knowledge to solve the problem. In some cases, depending on the purpose of learning, questions do not necessarily require answers beyond $\mathrm{C}$ if they simply ask for facts (e.g., who is the President of the United States?).

\subsection{Formative and Summative Assessments}

The course "English as an International Language" employs an assessment-based approach with active learning techniques such as group discussions and presentations. Students are formatively assessed throughout the course and constantly receive feedback (the advice that teachers or peers make) in the process of improving their performance towards the final exam. While the concept and practice of formative assessment have been under development, Torrance (2012), argues that it "provide[s] feedback to both students and teachers on student progress and what more might be done to facilitate such progress" (p. 324) and formative assessment is the "pedagogic process and the informal ways in which teachers come to understand student work and seek to assist their learning" (p. 325). According to Crisp (2012), formative assessment is "designed primarly to improve learning" and summative assessment "to judge learning [final evaluation]" (p. 33).

\section{Method}

This research paper is rather idiographic and intends to explain a unique and particular individual case. As Cohen et al. (2011, p. 161) explain, "[h]ow far they [group or individuals] are representative of a wider population or group is irrelevant, as much qualitative research seeks to explore the particular group under study, not to generalize." This research is expected to contribute to constructing or establishing a theory of assessment for learning by providing an example of an assessment-based approach. I consider this research as part of the teacher-as-researcher movement (Cohen et al., 2011, p. 31). 


\subsection{Teaching Method}

At the beginning of the course, I assured students that each time they raised their hands for questions or comments, they would receive one point as "students are motivated to learn when they ask the questions or perceive a need to know something" and "[u]sing questions in the classroom helps learners construct knowledge, index information, and retrieve information (Smart et al., 2012, p. 394). Also, "[t]he habit of asking good questions was most frequently mentioned as an essential component of critical thinking and problem solving skills...asking good questions, critical thinking, and problem solving go hand in hand" (Wagner, 2008, p. 14-15). To encourage students to ask questions, I told students that even if they scored 0 on the final exam, they would receive 100 points or $\mathrm{S}(\mathrm{A}+)$ if they raised their hand 100 times. As already mentioned, this practice takes advantage of students' extrinsic motivation for grades. I then paired up two students. This grouping has some advantages: 1) students can learn to work collaboratively and improve teamwork skills and 2) students can learn more broadly and deeply by exchanging ideas with each other through discussions and presentations. In the following section, I will explain how each session leads toward a collaborative and PBL learning environment orientated to performing well on the final exam.

\subsection{Course Structure}

In the first session, I started with an icebreaker activity where students got to know and introduced their partners in front of the rest of the class followed by my presentation about the course description. In the second session, each group then prepared and performed presentations. Groups were free to choose their topics, but the presentation had to relate to something international. One group performed a presentation about travelling to Germany and France. Another showed rankings of Japanese national sports such as soccer, tennis, and baseball. Another group did a presentation on imported motorcycles. This exercise helped students examine how much English is used (or not used) and the ways in which it is used in international contexts (e.g., travelling in Europe, the names of imported motor bikes).

In the third session, I provided each student with a series of articles about Japan's sociolinguistic landscape surrounding English and instructed them to read the articles for writing reports. This activity, albeit seemingly boring, provides fundamental knowledge necessary to further think of and discuss issues to new learning. It also promotes active learning as students learn about the subjects by conducting research and developing the core skills in the course objectives. The first article criticizes English dominance as the language of international business and affairs. The second article stands more or less neutral on the role of English in Japan. The third article is supportive of English.

The first article explains that there is a growing discourse that globalization is considered equivalent to being able to use English. The article warns that policy makers and English teachers discuss English education with caution. In the second article, the employees of Rakuten (a Japanese shipping service company) and UNIQLO (a Japanese clothe company) explain their companies' policy that adapted English as their official language. These companies started hiring more foreigners and obliging their Japanese employees to learn English. To get promoted in these companies, a high score (700 or above) in Test of English for International Communication (TOEIC) is required. The third article warns that without dramatically improving the English ability of their employees, Japanese companies are unlikely to grasp business opportunities. For example, even if they produce good products, they need English to explain and market the products internationally. After students read these articles, they summarized the content and expressed their own opinions in writing.

In the fourth session, students were instructed to create questions related to the course content for the final exam. Students were involved in the process of assessment so that "they feel a sense of ownership and responsibility" toward the course and its assessment (Sambell et al., 2013, p. 14). I told them that they would receive one point for each question that they created. If a group came up with 10 questions, for example, each student in the group would receive an extra 10 points. Students were quite enthusiastic and actively discussed and created questions. On average, each group created 10-15 questions for this exercise. I collected around 50 questions in total and removed redundant questions and questions irrelevant to the topic of the course. There were still around 30 questions left. For session 5, I printed out a list of these questions and asked the class to reduce the number of question to fewer than 10 based on their preference. The following questions were selected.

- What are the official languages of the United Nations other than English?

- What are the demerits (or risks) of not being able to speak English?

- Do you personally need English? Why? 
- Do you think more Japanese will learn English due to the Olympic Games that will take place in Tokyo in 2020 ? Why?

- Are you supportive of teaching English at elementary school? Why?

- Why is the official language of the International Olympic Committee (IOC) French?

- Why are Chinese and Koreans able to speak English better than Japanese?

In the sixth session, I gave students these questions in the form of an open-book practice test to encourage them to start studying and formulating ideas, connections, and extensions (ICE) that would be useful for the final exam. I let students work in pairs and search for information online or in the articles that they read. This way, students learned to work with others, deepened their understanding of the content and found new information about related issues. I asked them to discuss their answers with their partners. Some of their answers included the following:

\section{What are the demerits (or risks) of not being able to speak English?}

- Without speaking English, we might have a hard time finding a job (i.e., English helps to obtain a job).

- Without speaking English, we cannot make foreign friends / boyfriends / girlfriends.

\section{Do you need English? Why?}

- Yes, I do because I would like to talk to foreigners.

- Yes, I do because English is important as a communication tool.

- Yes, English is necessary due to globalization. Indeed, some companies such as UNIQLO and Rakuten made English their official language.

Do you think more Japanese will learn English due to the Olympic Games that will take place in Tokyo in 2020? Why?

- Yes, I do because a lot of foreigners will come to Japan. If we speak English, we will be able to help them, so the number of English learners will increase.

- Yes, I do because the companies that will be involved in the Olympic Games will hire English speakers to do business with foreigners.

- No, the number of English learners will not increase very much. Although those who work for some industries such as hotels and restaurants might need English, the Olympic Games are temporary.

Are you supportive of teaching English at elementary school? Why?

- Yes, I find it necessary. English is not about knowledge but technique. We should start learning as early as possible. This way, a barrier to English can be removed.

- No, I disagree with teaching English at the elementary level because there are many Japanese who became fluent in English after they started studying English at junior high school. That should be enough.

- No, teaching English at elementary school is not necessary. Elementary school students are unable to speak Japanese well. If they are given English education in elementary education, they will find it difficult to learn Japanese.

\section{Why is the official language of the IOC French?}

- It is because Mr. Pierre de Coubertin, who founded the International Olympic Committee in Paris, was French.

\section{Why are Koreans and Chinese able to speak English better than Japanese?}

- It is because Chinese and Koreans start learning English earlier than Japanese do. Furthermore, China has a one-child policy and parents can focus on educating their children more intensively.

- It is because unlike Japan, both countries stopped grammar-centered learning and teach conversational English which is more useful in real life.

- It is because Chinese and Koreans are aware of the importance of English while Japanese are not.

- It is because Chinese and Korean companies export their products to English-speaking countries; thus they have more opportunities to speak English. 
- It is because Japanese find it awkward to speak English while other Asians do not.

Their answers were relatively simple and often did not reflect reality (i.e., factual information was wrong). According to the ICE assessment model, most of their answers remained in the "I" stage (or less because they searched for information online and some of that information was incorrect). I thus challenged students about some of their answers. For instance, some students wrote that they needed English to talk to foreigners, but we then discussed that given the relatively small size of the English-speaking population in the world, the number of foreigners who speak English is limited. I continued to ask why only Japanese find it awkward to speak English while other Asians do not. I also asked them why they thought that Korean and Chinese companies export their products to English-speaking countries while Japanese companies do not. After the review, I encouraged them to explicitly express their own opinions in the final exam. If they simply wrote down facts, then they would be considered at the "I" stage and would receive the minimum amount of possible points (i.e. 5). If they stated their opinions and logically defended them, they would be at the " $\mathrm{C}$ " stage and would receive an additional 5 points. If they could further analyze issues and make suggestions to solve them, they would be at the "E" stage and receive the maximum amount of possible points (i.e. 15). Below is an example format for the ICE model.

Table 1. Rubric based on the ICE model

\begin{tabular}{lllll}
\hline & I & C & E & Total \\
\hline Question 1 & 5 & 5 & - & 10 \\
Question 2 & 5 & 5 & 5 & 15 \\
Question 3 & 5 & 5 & 5 & 15 \\
Question 4 & 5 & 5 & 5 & 15 \\
Question 5 & 5 & 5 & 5 & 15 \\
Question 6 & 5 & 5 & 5 & 15 \\
Question 7 & 5 & 5 & 5 & 15 \\
Total & & & & 100 \\
\hline
\end{tabular}

* The table constructed by the author based on Young and Wilson (1995)

In the practice test in response to the question of the demerits and/or risks of not being able to speak English, one student answered: "Without speaking English, 1) we will not get a job; 2) we cannot enjoy ourselves when traveling abroad; and 3) we cannot read publications and understand the media in English." If the student had stopped writing there, he would receive only 5 points as he would be at the "I" stage. However, he further went on to write as follows:

Demerit 1: We will not get a job.

Reasons: If we do not speak English, we will not be able to find jobs that require English such as business trips or job posts overseas. We will lose our business opportunities and earn less. To the contrast, if we speak English, we can gain trust from the boss and get promoted more easily.

Demerit 2: We cannot enjoy ourselves when traveling abroad.

Reasons: We will not be able to communicate and establish good relationships with foreigners. Also, when we get into trouble abroad such as pickpockets or luggage lifting, we cannot explain the problem in English and thus cannot receive help. It is troublesome to use a translation software.

Demerit 3: We cannot understand publications and the media in English.

Reasons: If we cannot read publications in English, our worldviews will be narrowed and limit the possibilities of our growth. Also, we might have problems with reading the instruction of imported goods such as medicine and food that do not have explanations in Japanese. They may contain allergic components.

The answer for the first demerit would receive 7 points as it lies somewhere between "I" and "C." While the student expressed his opinion, his reasoning is redundant to the demerit that he mentioned. The answer to the second demerit would receive 12 points as it provided examples of the demerit and touched upon a solution (i.e., a translation device), though this was not well articulated. The answer to the third demerit would receive 8 points. 
Although he provided examples for the demerit, he did not explain why our worldviews would be narrowed and limit the possibilities of our growth. He would score better if he provided figures (e.g., over $80 \%$ of the world publications and the media are in English) and explained what "our growth" means.

I revised the practice test, removing some questions, and adding some other questions for the final exam. I provided students with all these questions and discussed them in the seventh session before the final exam. I announced the marking criteria based on the ICE assessment model. The questions for the final exams were as follows:

- What are the official languages of the United Nations. Name them all. Also, why do you think German or Japanese are not UN official languages despite their economic powers?

- What are the demerits (or risks) of not being able to speak English? Provide three examples with reasons why they are demerits.

- Why is the official language of the IOC French?

- What is an international language? Please define the term with examples. Also, explain the relationships between globalization and international language(s).

- It is said that French was the international language in the $19^{\text {th }}$ century. How did English replace French and become the international language?

- Do you think teaching English is necessary in elementary education?

- Is there a language that could replace English as the international language? Please provide reasons.

\section{Results}

In the final exam, students' responses on average became more profound than their responses in the practice test. In response to the question "Do you think teaching English is necessary in elementary education?," for example, one student answered: "I do not think it is necessary to teach English at the primary level. While it is good to teach English when children are at elemantary school, if we teach English, other fundamental classes such as Japanese and Math will be sacrificed, and also it can be detrimental to Japanese identity formation. English is a communication tool and thus it is important to nurture skills to express before learning it." Another student answered: "No, I do not think teaching English in elementary education is necessary. At present, there is a lack of ALT [assistant language teachers], and they cannot be assigned to reach all elementary schools. Thus those who are not specialized in English education have to teach English. In this case, they have problems with pronunciation or writing and thus teach English poorly which has negative impact on students' English learning." Working on the questions for the final exam provided incentives for students to learn eagerly. Students really engaged in the course work and became proactive. As a result, their answers became more profound than the previous ones.

How did my students do in the final exam? Out of 100, the maximum score was 75 and the minimum was 41 . The average score was 55 and the median was 53. Class contribution points ranged between 11 and 42 . The average score was 21 and the median was also 21 . Why couldn't my students score higher than 75 in the final exam despite the fact that they had known the questions and discussed answers before the exam? It is arguably because the exam required students to apply their knowledge, reasoning, evidences and/or examples. This is the "E" stage in the ICE assessment model, which requires more time and effort for students to reach this stage.

\section{Discussion}

This paper provided an example of an assessment-based learning with active learning and the ICE model. The feedback from students after the course was positive. Some students wrote in the evaluation form: "I acquired various kinds of knowledge, not only about English but many others," "I did not get bored during the class because I had to keep working on something all the time," "It has been a long time since I concentrated on studying this hard," and "I was surprised at myself that I raised my hands so many times." However, it is difficult to quantify how assessment-based approaches are more engaging than non-assessment-based approaches. In other words, while formative assessments seem to help students understand teachers' expectations and get motivated for learning, it is doubtful whether formative assessment tasks are, as Bond and Falchikov (2006) frame, really student-centered. Even formative assessments, as with summative assessments, may be more teacher-centered than student-centered because teachers still decide what to do and judge students' performances. Also, while the assessment-based approach that I employed in this research was successful in bringing students up to the "C" stage, it is questionable whether more time (than 700 minutes), though necessary, would simply takes students to the "E" stage. My assessment-based approach depends on students' extrinsic 
motivation for grades, which may hinder students from deepening their learning, as intrinsically motivated learning is linked to a deep approach to learning (Peters, 2011; Tippin et al., 2002; Torrance, 2012). To address these issues, Crisp (2012) suggests integrative assessments, which provide students with opportunities to: 1) make judgements about their own learning or performance, 2) define standards and expectations in their responses, 3) track and analyze their approaches to responding to a problem, 4) integrate prior or current feedback into their response, and 5) engage with a meaningful task that has inherent worth beyond just an assessment activity. Finally, he argues, students should be "rewarded for the quality of their analysis of metacognitive abilities, rather than factual knowledge or a specific performance" (p. 41). This way, he concludes, "[s]tudents would be active partners in integrative assessments, whereas teachers would still be seen as being the primary controller for diagnostic, formative, and summative tasks" (p. 42).

Future research will be required to compare student evaluations of assessment-based approaches to student evaluations of non-assessment-based approaches. Also, the student evaluation did not mention how collaborative learning or working in teams helped their learning. An evaluation sheet should be developed to address this issue Despite these limitations, this course shows that assessment-based approaches can serve for student engagement and learning.

\section{Acknowledgements}

I am grateful to Mr. Ezra Anton Greene for editing this paper and the anonymous reviewer for his/her comment.

\section{References}

Boud, D., \& Falchikov, N. (2006). Aligning with long-term learning. Assessment \& Evaluation in Higher Education, 31(4), 399-413 http://dx.org/10.1080/02602930600679050

Clouder, L., Broughan, C., Jewell, S., \& Steventon, G. (2012). Improving Student Engagement and Development through Assessment. London and New York: Routledge.

Cohen, L., Manion, L., \& Morrison, K. (2011). Research methods in education. London and New York: Routledge.

Crisp, G. T. (2012). Integrative assessment: Reframing assessment practice for current and future learning. Assessment \& Evaluation in Higher Education, 37(1), 33-43. http://dx.doi.org/10.1080/02602938.2010.494234

Donnison, S., \& Penn-Edwards, S. (2012). Focusing on first year assessment: Surface or deep approaches to learning? The International Journal of the First Year in Higher Education, 3(2), 9-20. http://dx.doi.org/10.5204/intjfyhe.v312.127

Dyer, K. (2013). Improving Student Engagement - It's time for formative assessment. Retrieved February 20, 2014, from http://www.nwea.org/blog/2013/improving-student-engagement-its-time-for-formativeassessment/

Fink, L. D. (2003). Creating significant learning experiences: An integrated approach to designing college courses. San Francisco: Jossey-Bass.

Foster, E., McNeil, J., \& Lawther, S. (2012). Exploring new students' conceptions of engagement and feedback. In L. Clouder, C. Broughan, S. Jewell, \& G. Steventon (Eds.), Improving Student Engagement and Development through Assessment: Theory and Practice in Higher Education. London and New York: Routledge.

Greene, H. (2011). Freshmen marketing: A first-year experience with experiential learning. Marketing Education Review, 21(1), 79-87. http://dx.doi.org/10.2753/MER1052-8008210111

Hernandez, R. (2012). Does continuous assessment in higher education support student learning? Higher Education 64: 489-502. http://dx.doi.org/10.1007/s10734-012-9506-7

Keating, N., Zybutz, T., \& Rouse, K. (2012). Inclusive assessment at point-of-design. Innovative Education and Teaching International, 49(3), 249-256. http://dx.doi.org/10.1080/14703297.2012.703022

Kirk, K. (2013). Motivating students. Retrieved February 20, 2014, from http://serc.carleton.edu/NAGTWorkshops/affective/motivation.html

Lepper, M. R., Iyengar, S. S., \& Corpus, J. H. (2005). Intrinsic and Extrinsic motivational orientations in the classroom: Age differences and academic correlates. Journal of Educational Psychology, 97(2), 184-196. http://dx.doi.org/10.1037/0022-0663.97.2.184 
Mary, B. R. (1983). Getting Chemistry Off the Killer Course List. Journal of Chemical Education, Nov, 954-956. http://dx.doi.org/10.1021/ed060p913

Peters, R. A. (2011). Enhancing academic achievement by identifying and minimizing the impediments to active learning. Public Administration Quarterly, 35(4), 466-493. http://dx.doi.org/10.2307/23209325

Prince, M. (2004). Does active learning work? A review of the research. Journal of Engineering Education, 93(3), 223-231. http://dx.doi.org/10.1002/j.2168-9830.2004.tb00809.x

Rutherford, P. (2012). Active Learning and Engagement Strategies. Alexandria: Just AKS Publications \& Professional Development.

Sambell, K., McDowell, L., \& Montgomery, C. (2012). Assessment for Learning in Higher Education. London and New York: Routledge.

Smart, K. L., Witt, C., \& Scott, J. P. (2012). Toward Learner-Centered Teaching: An Inductive Approach. Business Communication Quarterly, 75(4), 392-403. http://dx.doi.org/10.1177/1080569912459752

Tippin, G. K., Lafreniere, K. D., \& Page, S. (2012). Student perception of academic grading: Personality, academic orientation and effort. Active Learning in Higher Education, 13(1), 51-61. http://dx.doi.org/10.1177/1469787411429187

Torrance, H. (2012). Formative assessment at the crossroads: Conformative, deformative and transformative assessment. Oxford Review of Education, 38(3), 323-342. http://dx.doi.org/10.1080/03054985.2012.689693

William, D., Lee, C., Harrison, C., \& Black, P. (2004). Teachers developing assessment for learning: Impact on student achievement. Assessment in Education, 11(1), 46-65. http://dx.doi.org/10.1080/0969594042000208994

Wagner, T. (2008). The global achievement gap: Why even our best schools don't teach the new survival skills our children need-And what we can do about it. New York: Basic Books.

Young, S. F., \& Wilson, R. J. (2000). Assessment \& Learning: The ICE Approach. Winnipeg: Peguis Publishers.

Young, S. F. (2005). Using ICE to improve student learning. A paper published in the Proceedings of the Improving Student Learning Symposium, London, UK, 13: 105-115. Imperial College, London, UK, September 2005. Oxford Center for Staff and Learning Development.

\section{Copyrights}

Copyright for this article is retained by the author(s), with first publication rights granted to the journal.

This is an open-access article distributed under the terms and conditions of the Creative Commons Attribution license (http://creativecommons.org/licenses/by/3.0/). 